\title{
Covid-19 dan Gerakan Sosial Perempuan
}

Indonesian Journal of Religion and Society, 2021, Vol. 03 (01), 21-32

(C) The Journal, 2021

DOI: $10.36256 /$ ijrs.v3i1.147

$\underline{\text { www.journal.lasigo.org/index.php/IJRS }}$

acis

aysournal

Article History

Received: May 20th, 2021

Revised: June 23th, 2021

Accepted: June 25th 2021

\author{
Ujang Wardi \\ Lasigo Akademia Indonesia \\ ujhegibear@gmail.com
}

\section{Elfia}

Universitas Islam Negeri (UIN) Imam Bonjol Padang, Indonesia

elfiamag@uinib.ac.id

\begin{abstract}
This study explains how social movements are initiated by women's groups. The movement carried out penetrates various spaces in the social environment and even traditional institutions as groups that have authority. Through a descriptive approach and in-depth interview techniques, this study answers questions about how women's groups carry out social movements by constructing the issue of the non-transparent distribution of Covid-19 aid. Thus, the mobilizing structure, which is carried out systematically, attracts traditional institutions (ninik mamak) in the vortex of conflict. This study found that the sources of issues from social movements carried out by women's groups were (a) information from the deputy governor regarding the distribution of Covid-19 aid, (b) nepotism and collusion from the nagari government. Two framing issues (framing) are then packaged through social media to attract the power to carry out mass actions (demonstrations). This study concludes that the demonstration of women giving birth is a new policy related to the distribution of Covid-19 by the government.
\end{abstract}

Keywords: Covid-19, Social Movement, Feminism.

\begin{abstract}
ABSTRAK
Studi ini menjelaskan tentang gerakan sosial (social movement) yang diinisiasi oleh kelompok perempuan. Gerakan yang dilakukan menembus berbagai ruang yang ada di lingkungan sosial bahkan institusi adat sebagai kelompok yang memiliki otoritas. Melalui pendekatan kualitatif deskriptif serta teknik wawancara mendalam, studi ini menjawab pertanyaan bagaimana kelompok perempuan melakukan gerakan sosial dengan cara mengkontruksikan isu ketidaktransparan pendistribusian bantuan Covid-19. Sehingga, struktur mobilisasi (mobilizing structure) yang dilakukan secara sistemik, menarik institusi adat (ninik mamak) dalam pusaran konflik. Studi ini menemukan bahwa sumber isu dari gerakan sosial yang dilakukan kelompok perempuan adalah (a) informasi dari wakil gubernur dalam pemerataan pembagian bantuan Covid-19, (b) nepotisme dan kolusi oleh pemerintahan nagari. Dua isu tersebut kemudian dikemas (framing) melalui media sosial dalam menarik kekuatan untuk melakukan aksi massa. Penelitian ini berkesimpulan bahwa demonstrasi perempuan mampu merubah kebijakan pendistribusian bantuan Covid-19.
\end{abstract}

Kata Kunci: Covid-19, Gerakan Sosial, Feminisme. 


\section{Pendahuluan}

Sejak Corona virus Dieses 2019 (COVID-19) ditetapkan sebagai wabah nasional pada 11 Maret 2020, pendistribusian bantuan Covid-19 oleh pemerintah memantik konflik di tengah masyarakat. Konflik tersebut terjadi disebabkan adanya ketidakpastian dan kepercayaan masyarakat terhadap kebijakan pemerintah terkait pendistribusian Bantuan Langsung Tunai (BLT), Bantuan Sosial (Bansos) dan Jaminan Pengaman Sosial (JPS) (Putra, 2020; Aminah, 2020; kompas.tv, 2020). Laporan Putra (2020) menjelaskan bahwa terjadinya demonstrasi disebabkan bahwa data penerima bantuan Covid-19 tidak lengkap dan tidak jelas. Selain itu studi Burhanuddin \& Abdi (2020) menjelaskan bahwa pemicu terjadinya konflik di tengah masyarakat tidak terlepas dari tersendatnya pendapatan ekonomi di tengah Pandemi Covid-19. Hal ini tidak hanya di Indonesia, anjloknya pertumbuhan ekonomi juga terjadi di berbagai negara di dunia, seperti China yang sebelumnya masuk kategori negara maju dengan pertumbuhan ekonomi 5,7\% turun menjadi 4,8\%. Tidak dapat dipungkiri bahwa kekhawatiran masyarakat terhadap kelangsungan hidup sangat tinggi disebabkan COVID-19. Hasil Survey Radio Republik Indonesia (RRI) dan Indo Barometer me publish bahwa tingkat kekhawatiran masyarakat terhadap Covid-19 mencapai 68 persen. Kekhawatiran masyarakat tersebut dibagi atas tiga, yakni 21, 3 persen sangat takut dan 46, 7 persen cukup khawatir, sedangkan yang tidak khawatir sebesar 30, 2 persen (Yahya, 2020). Segala sesuatu konflik bisa saja terjadi ketika kebutuhan yang paling mendasar bagi masyarakat tidak dapat dipenuhi (Webel \& Galtung, 2007).

Sejauh ini studi Covid-19 dan kaitannya dengan kehidupan sosial hanya terfokuskan terhadap beberapa aspek: Pertama sosial keagamaan, tentang bagaimana agama dapat menjadi penguatan mental, pergeseran pola ibadah, dan juga sebagai solusi terhadap masyarakat di tengah menghadapi Covid-19 (Jubba, 2021; Qudsy \& Sholahuddin, 2020; Saenong et al., 2020; Supriatna, 2020; Widjaja, Marisi, Togatorop, \& Hartono, 2020). Kedua, sosial ekonomi yang kaitannya lebih mendorong tindakan masyarakat dalam kewaspadaan akan dampak buruk dari segi pendapatan dan sistem perekonomian (Burhanuddin \& Abdi, 2020; Hanoatubun, 2020; Susilawati, Falefi, \& Purwoko, 2020; Ilyas, 2020). Ketiga kesehatan masyarakat, lebih melihat bahwa dampak Covid-19 berpengaruh buruk terhadap psikologis masyarakat serta mengantisipasi penularannya yang sangat massif terhadap kesehatan masyarakat (Abdullah, 2020; Mona, 2020; Rizal \& Hariandy, 2020; Tutmaner \& Awolich, 2020). Dari aspek di atas belum terlihat secara khusus menjelaskan bahwa Covid-19 telah menimbulkan sebuah gerakan demonstrasi bagi kelompok perempuan dalam menyuarakan pendapat di tengah ketidakadilan. Demonstrasi yang dilakukan kelompok perempuan disebabkan ketidaksiapan pemerintah dalam pendistribusian bantuan Covid-19 dan kemudian juga menimbulkan respon dari institusi adat (elit adat). Padahal institusi adat merupakan bagian terpenting dari pilar kehidupan masyarakat yang selalu dijaga agar tidak dicampuri oleh persoalan administratif (Shalihin, 2014).

Studi ini bertujuan untuk melengkapi kekosongan studi yang sudah ada melalui kajian yang lebih spesifik melihat bagaimana demonstrasi yang dilakukan oleh kelompok perempuan atas ketidaktransparan pendistribusian bantuan Covid-19 dan bagaimana keterlibatan institusi adat (ninik mamak)? Demonstrasi yang dilakukan oleh kelompok perempuan telah memperlihatkan potret kekuatan alam bawah sadar manusia ketika ketidakadilan telah merampas hak-hak masyarakat miskin di tengah krisis yang terjadi disebabkan Pandemi Covid-19. Demikian pula keterlibatan institusi adat (ninik mamak) dalam membela sanak kemenakan ketika kekuasaan melampaui dirinya dan menyasar kepada norma-norma dan budaya yang selama ini telah dijaga selama bertahun-tahun. Dengan demikian, selain menjadi telaah baru dalam melihat ketimpangan sosial dan ekonomi bagi akademisi, juga menjadi perhatian secara mendalam bagi pemerintah dalam mengevaluasi kebijakan terkait pendistribusian bantuan Covid-19 terhadap masyarakat yang lebih efektif.

Kajian ini didasarkan pada argumen bahwa kesiapan pemerintah dalam pendistribusian bantuan Covid-19, menimbulkan problematik yang riskan akan terjadinya konflik. Kebijakan pemerintah dengan memberi bantuan terhadap masyarakat agar tetap mematuhi himbauan Sosial Distance, Physical Distance, secara tidak langsung membuat masyarakat shock sehingga sulit menerima kehidupan yang di luar kebiasaan. Di tengah kehidupan yang tidak biasa, alih-alih pemerintah hadir dalam menjelaskan kondisi yang kongkrit dalam menghadapi Covid-19, ketidakefektifan kebijakan pemerintah justru telah menimbulkan konflik baru terkait pendistribusian bantuan Covid-19 terhadap masyarakat. 


\section{Kerangka Teori}

Dalam melihat demonstrasi perempuan, artikel ini menggunakan dua kerangka teoritik; pertama, dalam bingkai gerakan sosial, kedua, dalam bingkai feminisme. Dua teori ini merupakan teori yang relevan dalam mendiskusikan isu demonstrasi perempuan terkait pendistribusian bantuan Covid-19.

Gerakan sosial, seringkali muncul dalam pelbagai kebijakan yang sumbang dalam praktiknya. Dengan demikian, menimbulkan respon dari berbagai kelompok untuk melakukan perlawanan terhadap ketimpangan kebijakan. Ketimpangan kebijakan, seringkali muncul dari aspek ekonomi, politik dan agama (Jurdi, 2013). Sehingga, aspek demikian memancing tindakan kolektif (collective action) dari kelompok sosial.

Sebagaimana diketahui, gerakan sosial (social Movement) merupakan bagian terpenting dari perilaku kolektif (collective behavior). Setidaknya, dalam gerakan sosial memiliki tiga konsep; (1) struktur kesempatan secara politik, (2) struktur mobilisasi (mobilizing structure), (3) pembikaian aksi (framing). Tiga konsep ini merupakan langkah serta bentuk yang tepat dalam sebuah gerakan sosial (social movement) (Sukmana, 2016; Hasan, 2006).

Fenomena gerakan sosial (social Movement) seringkali muncul dengan perubahan struktur politik dan pergeseran pemahaman terhadap kebijakan. Dalam aksi massa, tidak hanya ditumpangi dengan adanya pergeseran kebijakan, melainkan adanya mobilisasi yang dilakukan secara sistemik. Selain itu, mobilisasi akan dimudahkan melalui media dalam pembingkaian isu (framing) untuk menarik kekuatan utuh dalam tindakan aksi (Hasan, 2006; Anam, Kolopaking, \& Kinseng, 2020).

Seturut dengan itu, adalah kelompok perempuan dalam gerakan sosial. Dalam ruang sosial, perempuan tidak hanya sebatas kasur, sumur dan dapur, melainkan memiliki haknya untuk sebuah kesetaraan dengan laki-laki. Kaum perempuan yang selama ini mengalami ketertindasan dan eksploitasi, pada akhir muncul untuk melakukan perlawanan. Mereka (kaum perempuan) selama ini hanya dipandang sebagai ke- "ibuan" yang tidak memiliki kemampuan dalam pergerakan. Pelabelan atas nama "perempuan", merupakan konstruksi yang liar dan hanya berorientasi sebatas seksualitas yang patriarkal (Hakim, 2020; Imron, 2015; Shalihin \& Firdaus, 2019).

Secara teoritik, gerakan kaum perempuan lebih dikenal dengan gerakan feminisme yang menuntut hak-hak kesetaraan. Kesetaraan hak, tidak hanya sebatas pengakuan dalam lingkungan sosial, namun juga berlaku dari semua lini kehidupan. Pengakuan yang diperoleh, merupakan perebutan eksistensi yang selama ini hanya melekat kepada kaum laki-laki (Hidayati, 2018).

Dalam gerakan feminisme, kaum perempuan memiliki soliditas yang terikat secara kolektif. Salah satu untuk menguji soliditas perempuan adalah ketika menuntut kebebasan "women's liberation". Meskipun, sempat dihalangi dengan pemunculan kesetaraan "equality right's movement" dengan laki-laki, perjuangan untuk kebebasan dan kemerdekaan oleh perempuan terus berlanjut dari berabad-abad silam (Luthfiyah, 2015; Hidayati, 2018).

\section{Metode Penelitian}

Studi ini merupakan penelitian lapangan dengan metode deskriptif kualitatif yang memberikan penjelasan langsung antara peneliti dengan informan. Sehingga mempermudah peneliti dalam memperoleh data dari perkataan dan perbuatan informan (Jhon, 2015; Koentjaraningrat, 1990; Moleong, 2012). Penelitian ini dilakukan di kenagarian Tanah Bakali Inderapura, Pesisir Selatan, Sumatera Barat, Indonesia. Nagari Tanah Bakali merupakan tempat berlangsungnya demonstrasi bagi kelompok perempuan yang berujung anarkisme. Tindakan anarkisme yang terjadi tidak hanya berlangsung antara kelompok perempuan dengan pemerintahan nagari (vertikal) namun menarik demonstrasi masyarakat secara luas dan juga melibatkan institusi adat (horizontal). Data yang diperoleh dan dikumpulkan melalui wawancara terhadap (1) Pelaku demonstrasi dari kelompok perempuan, (2) Ketua pemuda nagari, (3) Tokoh masyarakat dan ninik mamak. Data yang telah diperoleh kemudian dianalisis dengan langkah reduksi data, pemaparan bahan empirik, kemudian dilakukan penarikan kesimpulan dan verifikasi (Miles \& Huberman, 1992). Selain itu, data kemudian dianalisis menggunakan tahapan yang ditawarkan oleh Cresswell (2015). Tahapan pertama, manajemen data, di mana data yang diperoleh melalui wawancara diorganisasi ke dalam file-file dan mengonversi file-file tersebut menjadi satuan teks; kata, kalimat, cerita. Tahapan kedua, dengan melakukan pembacaan terhadap data dan memoing data. Sehingga data-data yang telah 
diorganisasikan ke dalam file-file; database dibaca berulang kali secara keseluruhan. Setelah pengorganisasian data selesai dilakukan, data-data tersebut kemudian diberi memo atau catatan singkat dan ringkas. Tahapan ketiga dengan cara deskripsi, klasifikasi dan penafsiran atas data. Data-data yang dibaca dan di memoing, berikutnya dilakukan deskripsi secara detail dalam rangka mengembangkan tema atau dimensi, dan memberikan penafsiran. Teknik deskripsi data ini dilakukan dengan cara mengelompokkan data teks atau visual menjadi kategori informasi yang lebih kecil, mencari bukti untuk kode tersebut. Setelah data dideskripsikan, maka tahap berikutnya adalah klasifikasi data dengan cara memilah-milah teks. Langkah berikutnya setelah dilakukan klasifikasi data adalah menafsirkan data agar dapat dimaknai. Keempat, visualisasi data. Data-data yang telah ditafsirkan dikemas dalam bentuk teks dan disajikan dalam bentuk naratif.

\section{Hasil dan Diskusi}

Ada tiga bentuk gerakan sosial yang terjadi terkait pendistribusian bantuan Covid-19 di Nagari Tanah Bakali Inderapura Pesisir Selatan; (a) gerakan kelompok perempuan, (b) memobilisasi massa, (c) institusi adat dalam pusaran konflik. Dari tiga point di atas, yang menjadi aktor penggerak lahirnya demonstrasi adalah "kelompok perempuan". Mereka (kelompok perempuan) yang selama ini di asumsikan tidak memiliki kekuatan, namun telah melakukan gerakan sosial.

Demonstrasi perempuan dimulai dari sebuah statement Wakil Gubernur Sumatera Barat (Nasrul Abit) yang menyatakan bahwa bantuan Covid-19 akan dibagikan secara merata. Bantuan yang akan dibagikan terdiri dalam tiga bentuk; pertama bantuan Pemerintah Pusat, kedua, bantuan pemerintah Provinsi, Ketiga, bantuan pemerintah Kabupaten dan keempat, bantuan dana desa/nagari. Selanjutnya porsi dan kriteria penerima bantuan berbeda-beda dan juga tata cara dalam pendistribusian bantuan Covid19. Setidaknya ada tujuh macam bantuan, 1) Bantuan Sosial (Bansos), 2) Bantuan Langsung Tunai (BLT/dana desa), 3) Bantuan Sembako, 4) Bantuan Sosial Tunai, 5) Listrik Gratis, 6) Kartu Pra Kerja, 7) Subsidi Gaji Karyawan.

Bagi masyarakat, mereka sama sekali tidak mengetahui bentuk-bentuk bantuan di atas termasuk tata cara dari penerimaan bantuan itu sendiri. Mereka hanya mengetahui bahwa akan ada bantuan Covid-19 dari pemerintah sesuai informasi yang mereka peroleh dari wakil gubernur Sumbar Nasrul Abit melalui media online.

Berbeda dari informasi yang diperoleh, pemerintah nagari justru meminta kepada masyarakat agar menyerahkan Kartu Keluarga (KK) dan Kartu Tanda Penduduk (KTP) sebagai prasyarat untuk menerima bantuan. Mereka yang tidak menyerahkan data di atas maka nama mereka tidak di daftarkan sebagai penerima bantuan. Ketimpangan informasi ini seketika mendapat kritikan dari masyarakat setempat bahwa pemerintah nagari sudah memiliki indikasi yang tidak baik dalam prosesi penyaluran bantuan Covid-19 terhadap masyarakat. Masyarakat berkeyakinan bahwa informasi dari Nasrul Abit merupakan informasi tertinggi yang menaungi nagari yang menyatakan bahwa bantuan akan dibagikan secara menyeluruh.

Perbedaan versi dalam penerimaan bantuan antara pemerintah provinsi dan pemerintah nagari menyebabkan tidak seluruh masyarakat yang menyerahkan KK dan KTP ke pemerintahan nagari. Dari jumlah $516 \mathrm{KK}$ yang berpenghasilan rendah dari $976 \mathrm{KK}$ yang terdaftar di pemerintahan nagari, hanya $27 \mathrm{KK}$ saja yang menyerahkan ke pemerintahan nagari. Sehingga himbauan pemerintahan nagari untuk menyerahkan prasyarat untuk memperoleh bantuan tidak di respon secara menyeluruh oleh masyarakat. Silang pendapat antara masyarakat dan pemerintah nagari tetap pada pendapat mereka masing-masing antara bantuan secara merata dan pemerintahan nagari dengan versinya. Akibatnya, perselisihan antara masyarakat dengan pemerintahan nagari semakin larut.

Puncaknya adalah setelah dua (2) minggu dari ketentuan untuk menyerahkan prasyarat. Pemerintah nagari, melalui perangkat nagari mengumumkan nama-nama sebagai penerima bantuan. Setidaknya ada beberapa kriteria penerima "Bantuan Langsung Tunai" (BLT) yaitu, (a) Ekonomi kalangan bawah: masyarakat yang sumber penghasilannya terdiri dari tukang ojek, petani harian, dan buruh bangunan. (b) Ekonomi kalangan menengah: masyarakat yang terdiri dari pedagang kaki lima, pedagang kelontong, supir travel. (c) Ekonomi kalangan atas: masyarakat yang sumber penghasilannya terdiri dari toke sawit, pensiunan PNS.

Dalam lanskap sosial, tiga point di atas merupakan masyarakat ideal sebagai penerima bantuan Covid-19. Tiga sumber penghasilan adalah masyarakat yang tidak dapat bergerak 
yang disebabkan bencana Covid-19. Dengan demikian, mereka merupakan orang-orang yang perlu di subsidi oleh pemerintah melalui bantuan. Adanya bantuan yang diberikan pemerintah, memungkinkan keresahan masyarakat dapat diatasi.

Pasca kebijakan terkait penerima bantuan ditetapkan pemerintah nagari, nama-nama tersebut disosialisasikan di kalangan masyarakat. Di beberapa tempat keramaian, pemerintah mengumumkan nama-nama sebagai penerima bantuan sekaligus menjelaskan kepada masyarakat, bahwa tidak semua masyarakat memperoleh bantuan. Salah satu perangkat nagari, DL menerangkan, dari awal pemerintah nagari sudah membuat skema kebijakan bahwa tidak semua masyarakat sebagai penerima bantuan Covid-19. Hal ini, menjadi keputusan bersama dengan Badan Musyawarah Nagari (BAMUS) dan tidak dapat diganggu gugat.

Titah ini menjadi memantik lahirnya kegaduhan awal antara masyarakat dan perangkat pemerintah nagari ketika berada di lokasi. Setidaknya, ada beberapa kericuhan yang terjadi, 1) pertengkaran fisik, 2) merusak lembaran pengaman, 3) mengusir secara tidak hormat keberadaan perangkat nagari pada saat pengumuman sedang berlangsung. Tiga kejadian di atas menyebabkan ketidaksenangan oleh pemerintah nagari maupun sebaliknya dari kalangan masyarakat.

Keputusan pemerintah nagari untuk tidak mengeneralisasi bantuan Covid-19 tetap dilakukan meskipun sudah mendapat protes dari masyarakat. Tindakan protes bagi masyarakat dinilai perangkat nagari adalah kesalahan masyarakat sendiri yang tidak mengindahkan himbauan sebelumnya dari pemerintah nagari untuk menyerahkan data mereka ke kantor Walinagari. Atas dasar, itu Walinagari memiliki alasan untuk tidak memproses masyarakat yang tidak terdaftar di kenagarian.

Bagi masyarakat, statement itu menjadi faktor ketersinggungan terhadap pemerintah nagari bahwa mereka seolah-olah tidak diakui dalam administrasi yang ada dalam pemerintahan nagari. Menurut keterangan AP menjelaskan, statement tersebut merupakan pernyataan identitas yang dapat menyinggung masyarakat secara luas. Lebih lanjut ia menjelaskan, bahwa pernyataan demikian adalah himbauan pemerintah untuk mengakui keberadaan mereka yang tidak mendukung kebijakan sepihak yang pemerintah nagari tetapkan.

Pada awalnya, konflik yang terjadi hanya pada tahapan perdebatan yang tidak melahirkan efek. Namun, tindakan tersebut lebih mengarah kepada gerakan sosial ketika terjadi pergandaan nama yang di publish oleh pemerintah nagari. Lebih lanjut, nama-nama sebagai penerima bantuan Covid-19 masih memiliki keterikatan kekeluargaan dengan Walinagari maupun berbagai perangkat nagari lainnya. Tidak hanya satu, nama yang tercantum melebihi dua orang dalam satu keluarga. Serentak dengan itu, IL menerangkan bahwa ia menemukan dalam daftar penerima bantuan terdapat PNS aktif yang merupakan penerima bantuan .

Adanya penggandaan nama sebagai penerima bantuan Covid-19 yang dilakukan oleh pemerintah nagari memantik lahirnya gerakan demonstrasi kelompok perempuan. Mereka (kaum perempuan) menilai bahwa Walingari dan perangkat nagari telah melakukan praktik nepotisme dan berkolusi dengan badan musyawarah nagari untuk melakukan penipuan bantuan Covid-19.

Pada awalnya kami heran karena nama-nama penerima bantuan itu aneh. Kita satu kampung dan kita mengetahui nama-nama orang kampung sini. Setelah saya baca nama-nama itu kemudian saya temui istrinya sudah ada sebagai penerima bantuan, setelah itu muncul lagi nama suaminya sebagai penerima bantuan. Padahal satu keluarga hanya boleh menerima satu bantuan saja. Terus saya bilang sama yang lain bahwa dua orang dapat bantuan dalam satu keluarga (AP, Wawancara Juni 2020).

Penemuan bukti penggandaan nama dalam menerima bantuan Covid-19, menguatkan keyakinan kelompok perempuan, bahwa Walinagari beserta jajaranya melakukan tindakan yang tidak baik terhadap masyarakat. Masyarakat menilai, Walinagari sebagai pemegang otoritas di pemerintahan nagari, mestinya dapat berlaku adil terhadap pendistribusian bantuan Covid-19. Lebih lanjut, apa bila tindakan yang demikian dibiarkan begitu saja, akan menurunkan tingkat kepercayaan masyarakat terhadap kinerja pemerintah. Atas tindakan demikian, masyarakat mesti melakukan konfirmasi dengan cara datang ke kantor Walinagari untuk mendapat keterangan lebih lanjut terkait kontroversi pendistribusian bantuan Covid-19.

\subsection{Gerakan Kelompok Perempuan}


Ada tiga bentuk gerakan sosial yang terjadi terkait pendistribusian bantuan Covid-19 di Nagari Tanah Bakali Inderapura Pesisir Selatan; (a) gerakan kelompok perempuan, (b) memobilisasi massa, (c) institusi adat dalam pusaran konflik. Dari tiga point di atas, yang menjadi aktor penggerak lahirnya demonstrasi adalah "kelompok perempuan". Mereka (kelompok perempuan) yang selama ini di asumsikan tidak memiliki kekuatan, namun telah melakukan gerakan sosial.

Demonstrasi perempuan dimulai dari sebuah statement Wakil Gubernur Sumatera Barat (Nasrul Abit) yang menyatakan bahwa bantuan Covid-19 akan dibagikan secara merata. Bantuan yang akan dibagikan terdiri dalam tiga bentuk; pertama bantuan Pemerintah Pusat, kedua, bantuan pemerintah Provinsi, Ketiga, bantuan pemerintah Kabupaten dan keempat, bantuan dana desa/nagari. Selanjutnya porsi dan kriteria penerima bantuan berbeda-beda dan juga tata cara dalam pendistribusian bantuan Covid19. Setidaknya ada tujuh macam bantuan, 1) Bantuan Sosial (Bansos), 2) Bantuan Langsung Tunai (BLT/dana desa), 3) Bantuan Sembako, 4) Bantuan Sosial Tunai, 5) Listrik Gratis, 6) Kartu Pra Kerja, 7) Subsidi Gaji Karyawan.

Bagi masyarakat, mereka sama sekali tidak mengetahui bentuk-bentuk bantuan di atas termasuk tata cara dari penerimaan bantuan itu sendiri. Mereka hanya mengetahui bahwa akan ada bantuan Covid-19 dari pemerintah sesuai informasi yang mereka peroleh dari wakil gubernur Sumbar Nasrul Abit melalui media online.

Berbeda dari informasi yang diperoleh, pemerintah nagari justru meminta kepada masyarakat agar menyerahkan Kartu Keluarga (KK) dan Kartu Tanda Penduduk (KTP) sebagai prasyarat untuk menerima bantuan. Mereka yang tidak menyerahkan data di atas maka nama mereka tidak di daftarkan sebagai penerima bantuan. Ketimpangan informasi ini seketika mendapat kritikan dari masyarakat setempat bahwa pemerintah nagari sudah memiliki indikasi yang tidak baik dalam prosesi penyaluran bantuan Covid-19 terhadap masyarakat. Masyarakat berkeyakinan bahwa informasi dari Nasrul Abit merupakan informasi tertinggi yang menaungi nagari yang menyatakan bahwa bantuan akan dibagikan secara menyeluruh.

Perbedaan versi dalam penerimaan bantuan antara pemerintah provinsi dan pemerintah nagari menyebabkan tidak seluruh masyarakat yang menyerahkan KK dan KTP ke pemerintahan nagari. Dari jumlah $516 \mathrm{KK}$ yang berpenghasilan rendah dari $976 \mathrm{KK}$ yang terdaftar di pemerintahan nagari, hanya $27 \mathrm{KK}$ saja yang menyerahkan ke pemerintahan nagari. Sehingga himbauan pemerintahan nagari untuk menyerahkan prasyarat untuk memperoleh bantuan tidak di respon secara menyeluruh oleh masyarakat. Silang pendapat antara masyarakat dan pemerintah nagari tetap pada pendapat mereka masing-masing antara bantuan secara merata dan pemerintahan nagari dengan versinya. Akibatnya, perselisihan antara masyarakat dengan pemerintahan nagari semakin larut.

Puncaknya adalah setelah dua (2) minggu dari ketentuan untuk menyerahkan prasyarat. Pemerintah nagari, melalui perangkat nagari mengumumkan nama-nama sebagai penerima bantuan. Setidaknya ada beberapa kriteria penerima "Bantuan Langsung Tunai" (BLT) yaitu, (a) Ekonomi kalangan bawah: masyarakat yang sumber penghasilannya terdiri dari tukang ojek, petani harian, dan buruh bangunan. (b) Ekonomi kalangan menengah: masyarakat yang terdiri dari pedagang kaki lima, pedagang kelontong, supir travel. (c) Ekonomi kalangan atas: masyarakat yang sumber penghasilannya terdiri dari toke sawit, pensiunan PNS.

Dalam lanskap sosial, tiga point di atas merupakan masyarakat ideal sebagai penerima bantuan Covid-19. Tiga sumber penghasilan adalah masyarakat yang tidak dapat bergerak yang disebabkan bencana Covid-19. Dengan demikian, mereka merupakan orang-orang yang perlu di subsidi oleh pemerintah melalui bantuan. Adanya bantuan yang diberikan pemerintah, memungkinkan keresahan masyarakat dapat diatasi.

Pasca kebijakan terkait penerima bantuan ditetapkan pemerintah nagari, nama-nama tersebut disosialisasikan di kalangan masyarakat. Di beberapa tempat keramaian, pemerintah mengumumkan nama-nama sebagai penerima bantuan sekaligus menjelaskan kepada masyarakat, bahwa tidak semua masyarakat memperoleh bantuan. Salah satu perangkat nagari, DL menerangkan, dari awal pemerintah nagari sudah membuat skema kebijakan bahwa tidak semua masyarakat sebagai penerima bantuan Covid-19. Hal ini, menjadi keputusan bersama dengan Badan Musyawarah Nagari (BAMUS) dan tidak dapat diganggu gugat.

Titah ini menjadi memantik lahirnya kegaduhan awal antara masyarakat dan perangkat pemerintah nagari ketika berada di lokasi. Setidaknya, ada beberapa kericuhan yang 
terjadi, 1) pertengkaran fisik, 2) merusak lembaran pengaman, 3) mengusir secara tidak hormat keberadaan perangkat nagari pada saat pengumuman sedang berlangsung. Tiga kejadian di atas menyebabkan ketidaksenangan oleh pemerintah nagari maupun sebaliknya dari kalangan masyarakat.

Keputusan pemerintah nagari untuk tidak mengeneralisasi bantuan Covid-19 tetap dilakukan meskipun sudah mendapat protes dari masyarakat. Tindakan protes bagi masyarakat dinilai perangkat nagari adalah kesalahan masyarakat sendiri yang tidak mengindahkan himbauan sebelumnya dari pemerintah nagari untuk menyerahkan data mereka ke kantor Walinagari. Atas dasar, itu Walinagari memiliki alasan untuk tidak memproses masyarakat yang tidak terdaftar di kenagarian.

Bagi masyarakat, statement itu menjadi faktor ketersinggungan terhadap pemerintah nagari bahwa mereka seolah-olah tidak diakui dalam administrasi yang ada dalam pemerintahan nagari. Menurut keterangan AP menjelaskan, statement tersebut merupakan pernyataan identitas yang dapat menyinggung masyarakat secara luas. Lebih lanjut ia menjelaskan, bahwa pernyataan demikian adalah himbauan pemerintah untuk mengakui keberadaan mereka yang tidak mendukung kebijakan sepihak yang pemerintah nagari tetapkan.

Pada awalnya, konflik yang terjadi hanya pada tahapan perdebatan yang tidak melahirkan efek. Namun, tindakan tersebut lebih mengarah kepada gerakan sosial ketika terjadi pergandaan nama yang di publish oleh pemerintah nagari. Lebih lanjut, nama-nama sebagai penerima bantuan Covid-19 masih memiliki keterikatan kekeluargaan dengan Walinagari maupun berbagai perangkat nagari lainnya. Tidak hanya satu, nama yang tercantum melebihi dua orang dalam satu keluarga. Serentak dengan itu, IL menerangkan bahwa ia menemukan dalam daftar penerima bantuan terdapat PNS aktif yang merupakan penerima bantuan .

Adanya penggandaan nama sebagai penerima bantuan Covid-19 yang dilakukan oleh pemerintah nagari memantik lahirnya gerakan demonstrasi kelompok perempuan. Mereka (kaum perempuan) menilai bahwa Walingari dan perangkat nagari telah melakukan praktik nepotisme dan berkolusi dengan badan musyawarah nagari untuk melakukan penipuan bantuan Covid-19.

Pada awalnya kami heran karena nama-nama penerima bantuan itu aneh. Kita satu kampung dan kita mengetahui nama-nama orang kampung sini. Setelah saya baca nama-nama itu kemudian saya temui istrinya sudah ada sebagai penerima bantuan, setelah itu muncul lagi nama suaminya sebagai penerima bantuan. Padahal satu keluarga hanya boleh menerima satu bantuan saja. Terus saya bilang sama yang lain bahwa dua orang dapat bantuan dalam satu keluarga (AP, Wawancara Juni 2020).

Penemuan bukti penggandaan nama dalam menerima bantuan Covid-19, menguatkan keyakinan kelompok perempuan, bahwa Walinagari beserta jajaranya melakukan tindakan yang tidak baik terhadap masyarakat. Masyarakat menilai, Walinagari sebagai pemegang otoritas di pemerintahan nagari, mestinya dapat berlaku adil terhadap pendistribusian bantuan Covid-19. Lebih lanjut, apa bila tindakan yang demikian dibiarkan begitu saja, akan menurunkan tingkat kepercayaan masyarakat terhadap kinerja pemerintah. Atas tindakan demikian, masyarakat mesti melakukan konfirmasi dengan cara datang ke kantor Walinagari untuk mendapat keterangan lebih lanjut terkait kontroversi pendistribusian bantuan Covid-19.

\subsection{Memobilisasi Massa}

Kedatangan para demonstran tidak gayung bersambut oleh pemerintahan nagari. Melalui keterangan IL, salah satu faktor penyebab memuncaknya emosi disebabkan kantor pelayanan yang tutup di saat jam kerja. Akibatnya, keberlangsungan demonstrasi menjadi tidak terkendali dan anarkisme. Para demonstran berkeyakinan, bahwa Walinagari dan perangkat nagari sengaja menghindari kedatangan para demonstran. Lebih lanjut IL menerangkan, tindakan untuk tidak berada di tempat, semakin menguatkan keyakinan para demonstran bahwa Walinagari dan perangkatnya telah melakukan penyelewengan kewenangan yang sedang dipegang.

Melalui orator, mereka menginstruksikan untuk membuka paksa kantor Walinagari. Narasi yang disampaikan oleh orator, bahwa tidak ada i'tikat baik dari Walinagari untuk memberikan penjelasan dan klarifikasi terkait pendistribusian bantuan Covid-19. 
Selain itu, di depan pintu kantor juga bertuliskan "pelayanan saat ini libur", padahal hari tersebut merupakan hari kerja bagi pemerintahan nagari untuk pelayanan masyarakat. Menurut para demonstran, hal yang demikian merupakan sewenang-wenang yang dilakukan oleh pemerintahan nagari terhadap amanah yang diemban. Tindak tersebut memicu pembukaan paksa terhadap pintu kantor yang terkunci.

Hal ini menjadi semakin tidak terkendali ketiga para demonstran memasuki ruang kerja pemerintahan nagari. Menurut AP, berbagai fasilitas kantor dirusak seperti; meja, kursi, komputer pelayanan, printer, lemari, pot bunga, kaca kantor, serta membakar arsip pemerintahan yang menelan anggaran berkisar Rp.200-400 Juta. Tindakan tersebut merupakan bentuk luapan kekecewaan akibat dari ketimpangan pelayanan yang dilakukan.

\begin{abstract}
Kedatangan kami memang ingin mempertanyakan kejelasan dari bantuan yang disalurkan oleh Walinagari. Namun saat kami datang ke kantor ternyata kantor tutup padahal masih jam kerja pukul 8,13. WIB. Kami yakin mereka (orang-orang pemerintahan nagari) sengaja menghindari kedatangan kami”. Hal demikian membuat kami emosi (Id, wawancara, Juni 2020).
\end{abstract}

Saya sama sekali tidak mengira bahwa akan terjadi kerusakan seperti itu. Karena pendemo hanya perempuan tidak mungkin akan merusak fasilitas. Tapi saya dan kawan-kawan sudah terlanjur sakit hati dan kecewa karena kedatangan kami tidak dianggap oleh pemerintah nagari. Menurut warga sekitar mereka awalnya ada di kantor dan kemudian pergi mendengar kami datang demo (AP, wawancara, Juni 2010).

Pada akhirnya, tindakan anarkisme para demonstrasi, berhasil dibubarkan oleh aparat kepolisian. Pihak kepolisian yang mendapat laporan terjadinya demonstrasi, segera datang ke lokasi kejadian. Melalui Camat, pihak kepolisian meminta para kelompok perempuan yang melakukan demonstran untuk membubarkan diri. Aparat kepolisian bersama Camat, memenuhi tuntutan yang disampaikan oleh para demonstran dan menindaklanjuti tuntutan kelompok perempuan serta berjanji akan mencari jalan keluar dari persoalan tersebut.

Pembubaran demonstrasi perempuan pada akhirnya tidak menemukan jalan keluar. Hal ini disebabkan bahwa pemerintahan nagari tidak terima perlakuan para demonstran yang telah merusak fasilitas kantor. Selain itu, menurut keterangan DD, bahwa Walinagari juga merasa bahwa para demonstran juga telah melakukan pencemaran nama baik secara pribadi. Pencemaran yang dilakukan dengan adanya atribut demo yang menuliskan bahwa Walinagari telah melakukan Nipotisme dan kolusi dalam pendistribusian bantuan Covid19. Untuk itu, pemerintah nagari dengan Bamus bermaksud akan melaporkan tindakan tersebut ke pihak kepolisian. Lebih lanjut, Walinagari sudah memiliki bukti dan mengantongi beberapa nama sebagai aktor demo dari perempuan yang merupakan tindakan provokasi untuk masyarakat lain.

Tindakan walinagari untuk melapor demonstrasi perempuan, mendapat respon lain dari masyarakat umum. Menurut keterangan AP, beberapa tokoh pemuda dan masyarakat, menilai tindakan Walinagari untuk melapor para demonstran perempuan merupakan tindakan yang di luar batas. Mestinya, Walinagari dapat mengevaluasi kebijakan yang dilakukan dan mempertimbangkan keputusan yang telah ditetapkan untuk kemaslahatan.

Sebetulnya, terlibatnya pemuda dan masyarakat disebabkan Pihak Nagari yang ingin melapor demo induak-induak (Perempuan). Mereka demo itukan hanya menyampaikan keinginan mereka yang tidak diperhatikan. Mestinya, Walinagari dan Bamus tidak usah merespon dan perbaiki saja jika ada kerusakan. Namun, adanya keinginan untuk melapor dan memenjarakan perempuan membuat tindakan tidak menyenangkan bagi masyarakat banyak (AP, wawancara, 2021).

Demonstrasi pada akhirnya tidak menemukan jalan selesai ketika pemerintahan berniat untuk melakukan pelaporan tindak pidana terhadap para demonstran perempuan. Sebaliknya, tindakan demikian telah memantik demonstrasi susulan dari pihak masyarakat banyak. Masyarakat menilai, tindakan Walinagari untuk melapor merupakan itimidasi terhadap kaum perempuan.

Siang, ba'da Jum'at, demonstrasi kembali berlangsung di kantor pemerintahan nagari. Gerakan yang dilakukan pemuda dan masyarakat, agar Walinagari mencabut pelaporan terhadap kelompok perempuan, serta menuntut untuk memenuhi tuntutan dari kelompok perempuan. 
Walhasil, demonstrasi menemukan jalan keluar yang difasilitasi oleh pihak kepolisian, tim kecamatan, dan DPRD Provinsi. Melalui musyawarah, pihak Kecamatan dan DPRD Provinsi menyerahkan agar penyelesaian dapat difasilitasi oleh adat.

\subsection{Institusi Adat dalam Pusaran Konflik}

Pada akhirnya, anarkisme demonstrasi, menyebabkan polarisasi; tidak hanya pertikaian antara kelompok perempuan dengan pemerintahan nagari, namun, juga menarik institusi adat dalam pusaran konflik. Setidaknya, ada beberapa faktor keterlibatan institusi adat dalam pusaran konflik; a) penyelesaian konflik yang terjadi, b) menarik ninik mamak sebagai mediator, c) mendorong ninik mamak sebagai aktor pendistribusian bantuan Covid19. Tiga point di atas merupakan proses keterlibatan institusi adat dalam pertikaian yang terjadi.

Pasca terjadinya demonstrasi, proses penyelesaian beralih fungsi ke institusi adat. Konflik antara masyarakat dengan pemerintahan nagari sepenuhnya menjadi tanggung jawab ninik mamak dalam proses perdamaian. Melalui forum musyawarah di aula kecamatan, camat menerangkan bahwa pertikaian yang terjadi merupakan sebuah kesalahpahaman yang tidak berdasar. Menurut keterangan AP, kesalahpahaman tidak berdasar yang dijelaskan oleh Camat, merupakan pembuktian antara tuntutan dan pelaporan oleh masyarakat dan Walinagari tidak berdasarkan pembuktian yang dapat dijelaskan di depan hukum. Untuk itu, pertikaian yang terjadi diserahkan kepada institusi adat dalam proses mendamaikannya.

Pada awalnya, keterlibatan ninik mamak dalam musyawarah penyelesaian konflik tidak mendapat protes dari masyarakat. Sebagai tetua dalam kaum, mereka tentulah mesti dihormati. Selain itu, mereka merupakan representasi dari tokoh panutan yang juga memiliki nilai-nilai penghormatan dari sanak dan kemenakan. Dalam arti yang lebih jauh, mereka merupakan percontohan bagi generasi muda dari basis suku.

Namun, yang menjadi konflik bagi masyarakat adalah terkait pendistribusian bantuan yang diserahkan oleh pemerintahan kepada institusi adat. Ninik mamak sebagai aktor pendistribusian, merupakan tindakan yang dianggap tidak menghormati institusi. Menurut $\mathrm{BB}$, pemerintah tidak bisa memisahkan antara kewenangan pemerintahan dengan kewenangan adat.

Para tetua adat (ninik mamak) merupakan pemegang kekuatan dalam adat. Mereka mesti dihargai dengan kewenangan yang mereka miliki dalam adat. Menyuruh mereka sebagai aktor pendistribusian adalah sikap yang tidak tepat oleh pemerintah nagari maupun ninik mamak sebagai penerima kewenangan (BB, wawancara, Juni 2020).

Keterlibatan Institusi adat dalam pendistribusian bantuan Covid-19 mendapat protes dari masyarakat. Mereka menilai, ninik mamak bukan ditugaskan adat untuk membagikan sembako dan bantuan, melainkan menyelesaikan "kusuik nan ndak salasai" (konflik yang sedang terjadi). Jika di biarkan, akan berdampak terhadap moralitas gelar "kaum" yang sedang mereka jalani.

Meskipun tidak mendapat perlawanan seperti yang dialami oleh pemerintah nagari, di mata masyarakat, tindakan demikian merupakan amoral yang tidak dapat dijadikan percontohan untuk masa yang akan datang. Sebagai orang tetua dalam adat, ninik mamak mestinya menolak permintaan pemerintahan nagari sebagai aktor pendistribusian. Pada tahapan ini, masyarakat hanya dapat menerima dengan berlapang hati dalam ketimpangan pendistribusian yang dilakukan.

\section{Diskusi}

Bagian ini memperlihatkan bahwa Pandemi Covid-19 telah membuka ruang terjadinya gerakan sosial (social movement). Gerakan yang terjadi justru di inisiasi oleh kelompok perempuan sebagai aktor. Perempuan yang selama ini dianggap sebagai pelengkap dalam sebuah perkawinan, pada akhirnya mampu melahirkan sebuah demonstrasi yang terukur. Hal ini dibuktikan ketika terjadinya ketimpangan kebijakan yang dilakukan oleh pemerintahan nagari di Tanah Bakali, Inderapura, Pesisir Selatan.

Aksi massa yang dilakukan oleh kelompok perempuan merupakan tindakan pembuktian di ruang sosial, bahwa perempuan mesti diakui eksistensinya di depan publik. Pembuktian tersebut, ketika yang menjadi hak-ekonominya direbut secara parsial oleh kekuasaan Walinagari. Melalui forum terbuka seperti aksi massa, mereka menyampaikan 
tuntutan yang mesti mereka peroleh dari kebijakan yang ditetapkan pemerintah nagari (Mufida, 2020; Zainul, 2020).

Dalam konteks gerakan, ekonomi menjadi salah satu faktor dominan bagi kelompok perempuan melakukan tindakan kolektif (collective action). Adanya pengaruh yang lahir dari lingkungan sosial, menjadi bagian kelindan dalam memengaruhi psikologi berbagai individu untuk melakukan gerakan. Secara struktur kesempatan politik, pembikaian isu ekonomi memudahkan dalam melakukan mobilisasi untuk aksi massa (Hasan, 2006; Soeparno \& Sandra, 2011). Terlebih, kelompok perempuan sangat diuntungkan perkembangan dunia digitalisasi untuk memperoleh berita dari media sosial (Anam et al., 2020).

Ketidakpuasan atas kebijakan, serta ketimpangan regulasi dalam pendistribusian bantuan yang ditetapkan pemerintah, mendorong kelompok perempuan untuk melakukan demonstrasi. Ketidakhati-hatian pemerintah dalam menetapkan kebijakan (policy) pendistribusian bantuan Covid-19, dilihat sebagai kerangka absural yang mesti dilawan oleh kelompok perempuan. Dari ketimpangan yang berlangsung; ketidaksiapan pemerintah dalam penanggulangan bencana, serta lembaga dari pembuat kebijakan jelas tidak terancang dengan baik (Tutmaner \& Awolich, 2020; Agung, Indra, \& Satya, 2020).

\section{Kesimpulan}

Kaum perempuan dalam gerakan sosial (social movement) bukanlah suatu yang baru dalam dunia gerakan. Seringkali, kaum perempuan mewarnai berbagai aksi massa ketika adanya ketimpangan kebijakan yang ditetapkan pemerintah. Terlebih, ketimpangan yang lahir dari kebijakan pemerintah lebih bergelayutan pada sisi ekonomi. Peran perempuan cenderung lahir dari urusan semacam itu dalam memperoleh haknya dalam kesetaraan.

Dalam pendistribusian bantuan oleh pemerintah nagari di Tanah Bakali, Inderapura, Pesisir Selatan, kelompok perempuan datang untuk melakukan perlawanan terhadap ketimpangan kebijakan. Mereka (kelompok perempuan) menilai, bahwa kebijakan telah mencederai hak-haknya dalam memperoleh bantuan Covid-19. Melalui demonstrasi, mereka datang ke pusat pemerintahan nagari untuk melakukan perlawanan dengan terjadi nipotisme dan kolusi yang disebabkan pemerintahan nagari.

Gerakan sosial yang pada dasarnya hanya pada tataran kaum perempuan saja, pada akhirnya mampu melahirkan gerakan massa yang lebih besar. Melampaui itu, juga menarik institusi adat dalam mewarnai aksi mereka. Institusi adat dalam kerangka Minangkabau merupakan otoritas yang kuat yang seringkali memiliki pelbagai pertimbangan dalam memutuskan tindakan yang diambil. Dalam konteks aksi massa yang terjadi, kelompok perempuan dapat menarik institusi adat dalam pusaran konflik yang terjadi. Meskipun pada akhirnya, institusi adat melakukan tindakan yang di anggap tidak dapat memisah dan memilah dalam menentukan tindakan yang dilahirkan.

\section{Ucapan Terima Kasih}

Ucapan terima kasih disampaikan kepada semua pihak yang telah membantu proses penelitian, penulisan dan publikasi artikel ini.

\section{Konflik Kepentingan}

Penulis menyatakan bahwa tidak ada konflik kepentingan antar penulis dan subjek penelitian dalam penulisan artikel ilmiah ini.

\section{Daftar Pustaka}

Abdullah, I. (2020). Psychological Trauma: Theory, Research, Practice, and Policy COVID19: Threat and Fear in Indonesia. American Psychological Association, 1.

Agung, P., Indra, N., \& Satya, P. (2020). COVID- 19 dan Potensi Konflik Sosial.

Aminah, A. N. (2020). Pembagian Sembako Ricuh, Bupati Bogor Tegur Ketua Baznas.

Anam, K., Kolopaking, L. M., \& Kinseng, R. A. (2020). Efektivitas Sosial Media Dalam Gerakan Sosial Penolakan Reklamasi Teluk Jakarta, Indonesia. Sodality: Sosiologi Pedesaan, 08(01), 64-81. https://doi.org/10.22500/8202028955

Burhanuddin, C. I., \& Abdi, M. N. (2020). Ancaman Krisis Ekonomi Global Dari Dampak Penyebaran Virus Corona (COVID-19). AkMen, 17 Nomor 1(March), 710-718.

Creswell, J. W. (2015). Penelitian Kualitatif dan Desain Riset. Pustaka Pelajar. https://doi.org/10.1016/S0953-7562(10)80014-0

Hakim, L. (2020). Corak Feminisme Post-Modernis Dalam Penafsiran Faqihuddin Abdul 
Kodir. Studi Imu-Ilmu Al-Qur'an Dan Hadis, 21(1), 231-253. https://doi.org/10.14421/qh.2020.2101-12

Hanoatubun, S. (2020). Dampak Covid-19 Terhadap Perekonomian Indonesia. EduPsyCouns, 2(2716-4446), 146-153.

Hasan, N. (2006). Book Review : Islam Politik , Teori Gerakan Sosial , dan Pencarian Model Pengkajian Islam Baru Lintas-Disiplin. Al-Jami'ah, 44(1).

Hidayati, N. (2018). Teori Feminisme: Sejarah, Perkembangan dan Relevansi dengan Kajian Keislaman Kontemporer. Harkat, 14(1), 21-29.

Ilyas, A. (2020). Covid-19 Pandemic: Economic Choices in Times Of Corona. Sustainable Development Policy Instittuet, 17-20.

Imron, A. (2015). Dekonstruksi Kultural Terhadap Feminisme Dan Dekonstruksi Feminis Terhadap Kultur Dalam Cerpen Malam Pertama Seorang Pendeta. Transformatika: Jurnal Bahasa, Sastra, Dan Pengajarannya, 11 (September), 72-79.

Jhon, C. W. (2015). Penelitian Kualitatif \& Desain Riset; Memilih di Antara Lima Pendekatan Edisi Ke 3. Pustaka Pelajar.

Jubba, H. (2021). Beradaptasi dengan Bencana: Strategi Beribadah Umat Islam dan Kristen di Tengah Pandemi Covid-19. Religious: Jurnal Studi Agama-Agama Dan Lintas Budaya, 5(1), 1-14. https://doi.org/10.15575/rjsalb.v5i1.11164

Jurdi, S. (2013). Gerakan Sosial Islam: Kemunculan, Eskalasi, Pembentukan Blok Politik dan Tipologi Artikulasi Gerakan. Politik Profetik, 1(1).

Koentjaraningrat. (1990). Metode-metode Penelitian Masyarakat. PT Gramedia Pustaka Utama.

kompas.tv. (2020). Ricuh! Pembagian Bansos Tak Adil, Warga Bakar Posko Corona.

Luthfiyah, N. (2015). Feminisme Islam Di Indonesia. Esensia, 16(1).

Miles, M. B., \& Huberman, M. (1992). Analisis Dara Kualitatif. Universitas Indonesia.

Moleong. (2012). Metode Penelitian Kualitatif. PT. Remaja Rosdakarya.

Mona, N. (2020). Konsep Isolasi dalam Jaringan Soisal Untuk Meminimalisasi Efek Contagious (Kasus Penyebaran Virus Corona di Indonesia). Sosial Humaniora Terapan, 2(2), 117-125.

Mufida, A. (2020). Polemik Pemberian Bantuan Sosial Di Tengah Pandemic Covid 19. Adalah Buletin Hukum \& Keadilan, 4(2338-4638), 159-166.

Putra, P. (2020). Pembagian Bansos Ricuh Diduga Salah Prosedur, Ini Penjelasan PT. Pos.

Qudsy, S. Z., \& Sholahuddin, A. (2020). Kredibilitas Hadis dalam COVID-19 : Al Quds, 4, 1-18. https://doi.org/10.29240/alquds.v4i1.1476

Rizal, A., \& Hariandy, A. (2020). Social responsibility of medical journal : a concern for COVID-19 pandemic. Medical Journal of Indonesia, 29(1), 1-3. https://doi.org/10.13181/mji.ed.204629

Saenong, F. F., Zuhri, S., Hasan, H., Halimin, M., Lodji, M., Nawawi, A. M., Abidin, Z., Kuba, A., Iskandar, S., Adnan, M., Tandos, R., Nurhayati, C., \& Hasanuddin. (2020). Fiqih Pandemi Beribadah Di Masa Wabah (S. Iskandar (ed.)). NUO PUBLISHING.

Shalihin, N. (2014). Demokrasi di Nagari Para Tuan (M. Sholihin (ed.); 1st ed.). Imam Bonjol Press.

Shalihin, N., \& Firdaus, F. (2019). Transformasi Gender: Strategi Pembebasan Perempuan dari Jerat Pembangunan dan Kapitalisme. Sawwa: Jurnal Studi Gender, 14(1), 109140. https://doi.org/10.21580/sa.v14i1.3366

Soeparno, K., \& Sandra, L. (2011). Social Psychology : The PasION. Buletin Psikologi, 19(1), $16-28$.

Sukmana, O. (2016). Konsep dan Teori Gerakan Sosial (1st ed.). Intrans.

Supriatna, E. (2020). Wabah Corona Virus Disease Covid 19 Dalam Pandangan Islam $\square$. Salam, Sosial Dan Budaya Syar-I, 7(Covid 19), 555-564. https://doi.org/10.15408/sjsbs.v7i6.15247

Susilawati, Falefi, R., \& Purwoko, A. (2020). Impact of Covid- 19's Pandemic on the Economy of Indonesia. BIRCI, 1147-1156.

Tutmaner, N., \& Awolich, A. (2020). The Covid-19 Pandemic Vulnerability Factor In South Sudan. The Sudd Institute.

Webel, C., \& Galtung, J. (2007). Handbook Of Peace and Conflict Studies. Routledge.

Widjaja, F. I., Marisi, C. G., Togatorop, T. M. T., \& Hartono, H. (2020). Menstimulasi Praktik Gereja Rumah di tengah Pandemi Covid-19. Kurios Teologi Dan Pendidikan Agama Kristen, 6 Nomor 1(May), 127-139. https://doi.org/10.30995/kur.v6i1.166

Yahya, A. N. (2020). Survei RRI-Indo Barometer: Tingginya Kekhawatiran Warga atas Wabah 
32 | Ujang Wardi \& Elfia

Covid-19 Artikel ini telah tayang di Kompas.com dengan judul "Survei RRI-Indo Barometer: Tingginya Kekhawatiran Warga atas Wabah Covid-19", https://nasional.kompas.com/read/2020/03/20/1318.

Zainul, H. (2020). Malaysia's Infodemic and International Studies. Institute Of Strategic And Policy Respons. 